Hydrol. Earth Syst. Sci. Discuss., doi:10.5194/hess-2016-544, 2016

Manuscript under review for journal Hydrol. Earth Syst. Sci.

Published: 18 November 2016

\title{
Flood modeling can make a difference: Disaster risk-reduction and resilience-building in urban areas
}

Jorge A. Ramirez ${ }^{1}$, Umamaheshwaran Rajasekar ${ }^{2}$, Dhruvesh P. Patel ${ }^{3}$, Tom J. Coulthard ${ }^{4}$, Margreth Keiler $^{1}$

$5 \quad{ }^{1}$ University of Bern, Institute of Geography, Bern, Switzerland

${ }^{2}$ TARU Leading Edge Pvt. Ltd., New Delhi, India

${ }^{3}$ School of Technology, Pandit Deendayal Petroleum University, Gujarat, India

${ }^{4}$ School of Environmental Sciences, University of Hull, Hull, United Kingdom

Correspondence to: Jorge A. Ramirez (jorge.ramirez@giub.unibe.ch)

10 Abstract. Surat, India is a coastal city with a population of approximately 4.5 million people that lies on the banks of the river Tapi and is located $100 \mathrm{~km}$ downstream from the Ukai dam. Given Surat's geographic location the city is repeatedly exposed to flooding caused by large emergency dam releases into the Tapi river combined with high tide water levels. Flood events of this type occur twice a decade, but their frequency and magnitude may increase due to the urbanization, encroachment in flood plain and climate change. A first step towards strengthening resilience in Surat requires a robust method for mapping flood exposure at fine spatial resolution. Here, in this study we have developed such a method for Surat using a reduced-complexity hydrodynamic model to simulate flooding, but is easily transferable to other urban locations. Our method features three distinct phases that involve: 1) modelling dam release discharge from the Ukai dam arriving at Surat, 2) modelling flooding within Surat caused by the combination of dam release and tides, and, 3) identifying Surat critical infrastructure, population, and income groups exposed to flooding. Our flood model of Surat utilizes topography produced using elevation data collected from

20 an extensive survey. Within the city we have modelled flood scenarios that represent the uncertainty in flood peak discharge and duration resulting from possible climate change. These scenarios include catastrophic conditions that flood $50 \%$ of the city and expose $>60 \%$ of the population and critical infrastructure to deep flooding. Finally, we highlight how our modelling has contributed to changes in flood risk management within the city following a major flood and resulted in actions that have increased community resilience to flood hazard.

\section{Introduction}

Recent efforts in hydrology have highlighted the need to consider the impact that society has on flooding (Baldassarre et al., 2013; Di Baldassarre et al., 2015). Of importance is determining the combination of physical processes and human dynamics that create conditions leading to flood disasters and increased human exposure to flooding. Physical processes can include long-term climatic changes that increase the occurrence of short-term extreme precipitation events triggering flash floods 30 within rivers. Likewise changes in population, land use, and economics can encourage settlements within floodplains and 
Hydrol. Earth Syst. Sci. Discuss., doi:10.5194/hess-2016-544, 2016

subsequently create the need for flood protection measures (e.g. dams, levees, canals) that significantly alter river processes (Wohl et al., 2015). Globally these societal pressures are most apparent in urban areas that are undergoing rapid development (Seto et al., 2011) and an expected 60\% increase in population (4 to 6 billion) by 2050 (United Nations, 2015). This projected urban expansion will mostly occur in Asia, specifically in locations with dense populations and low topography susceptible to

5 flooding (Güneralp et al., 2015; Jongman et al., 2012). For these reasons there is an urgent need to estimate flood exposure in Asian urban cities as well as translate these estimates into actions to reduce exposure and disaster risk to urban inhabitants and critical infrastructure.

One method to estimate flood exposure are computer models that generate predictions of flood inundation that can be spatially 10 overlaid on maps of population, critical infrastructure, and income groups. For example, recent advances in reducedcomplexity flood models (Bates et al., 2010; Coulthard et al., 2013a) with simplified physics have shown promise in estimating flood depths, extent and velocity in urban areas (Fewtrell et al., 2011; Ramirez et al., 2016; Sampson et al., 2014). These models are particularly suited for data sparse locations, with large spatial extents $\left(>500 \mathrm{~km}^{2}\right)$, and urban topography represented by fine spatial resolution $(\leq 30 \mathrm{~m})$ digital elevation models (DEMs). Moreover, open source software and the low

15 computational overhead needed for such reduced-complexity modelling facilitates the generation of multiple model runs that produce flood maps representing ensemble simulations of various flood scenarios. As such, flood exposure estimated with reduced-complexity models can explore uncertainty stemming from environmental forcings that result in various flood return periods and duration. Herein we use a freely available, reduced-complexity flood model to estimate flood exposure for the first time in a large, densely populated city in northwest India where human intervention (e.g. dam and levee construction) and

20 demands on the hydrological cycle (e.g. water for irrigation) has contributed towards multiple catastrophic floods. Like many urban areas, flood mapping and exposure assessment in our study site is challenged by the scarcity of available data, in this paper methods to gather such data and forecast flood inundation using open-source software are presented. An important part of this research is how results from our model have directly motivated changes in the way local authorities are preventing future floods and increasing the resilience of the city.

\section{Data and methods}

\subsection{Study site}

In India, the National Disaster Management Authority has provided guidelines that specify that all cities prone to flood have a detailed flood preparedness plan prepared at the ward level (city administrative unit). These efforts are intended to "minimise vulnerability to floods and consequent loss of lives, livelihood systems, property and damage to infrastructure and public

30 utilities" (National Disaster Management Authority, 2008). Recent enforcement has led cities to compile a database of resource inventory which includes tools and equipment needed for response post flooding. Surat, is one of these cities, and is located in the northwest of India near the Arabian Sea and is a major port, industrial, and commercial center (Fig. 1c). Surat is the seventh 
Hydrol. Earth Syst. Sci. Discuss., doi:10.5194/hess-2016-544, 2016

largest city in India with an area of $325,000 \mathrm{~km}^{2}$ and a population of 4.5 million. From 1990-2014 the city underwent considerable urban development within the Tapi river floodplain that resulted in a 170\% increase in urban land cover (Misra and Balaji, 2015). Upstream from Surat the Tapi river has an approximate length of $634 \mathrm{~km}$ up to the origin and a catchment area of $62,000 \mathrm{~km}^{2}$ (Fig. 1a). The catchment lies within a highly variable rainfall zone where $90 \%$ of the annual rainfall is

5 received during the monsoon months (June to October) and an average annual rainfall of $830 \mathrm{~mm}$ (Kale and Hire, 2004). In order to address the problem of flooding in Surat, storing water for summer irrigational needs, and hydropower the government of India constructed the Ukai dam on the river Tapi in 1971 (Fig. 1b). The multi-purpose nature of the dam forces the irrigation authorities to conserve water to the maximum allowable capacity of the reservoir during the monsoon. Thus, any extreme rainfall experienced at the end of the monsoon leads to unplanned releases of water from the reservoir that may cause flooding

$10100 \mathrm{~km}$ downstream within Surat. As such, since the construction of the dam floods in Surat are socio-natural hazards (Birkmann et al., 2013) because flood events are caused by the combination of natural phenomena (e.g. rainfall) and manmade causes (e.g. dam mismanagement). Over the past half century the city has experienced on average two floods per decade that were caused by dam releases. This includes catastrophic flood in the years of 1994, 1998 and 2006. The most recent flood in August 2006 was the result of intense rainfall in the Tapi catchment that led to a 15 day dam release with a peak discharge

15 near 25,000 $\mathrm{m}^{3} \mathrm{~s}^{-1}$ (avg. discharge $=9,300 \mathrm{~m}^{3} \mathrm{~s}^{-1}$, low flow $=640 \mathrm{~m}^{3} \mathrm{~s}^{-1}$ ). During this catastrophic flood 75\% of the city was flooded, an estimated $40 \%$ of the city inhabitants received no warning about the dam release, human deaths totalled 300 and damages exceeded 3 billion USD (Bhat et al., 2013; Patel and Srivastava, 2013). Since 2006 embankments alongside the river have been raised and no major floods have occurred, but the effectiveness of these embankments is questionable because future climate change within the Tapi basin during the monsoon season is expected to have a 30\% increase in rainfall (Mishra and

20 Lilhare, 2016) and increased occurrence of extreme rainfall events (200-350 mm/day) (Bhat et al., 2013; Deshpande et al., 2016). These climatic changes may result in a 75\% increase stream flow for the Tapi river (Mishra and Lilhare, 2016) and subsequently result in unprecedented emergency dam releases that produce flooding in Surat. Although climate change will be a major driver of future flooding in Surat, likewise urban flood risk will also be strongly dependent on the increase of urban expansion in the city stemming from socio-economic changes (Güneralp et al., 2015). Foreseeing future flood disasters,

25 activities have been developed by the Surat Municipal Corporation and a commissioner that supervises flood management activities with the support from ward level engineers. One effort enacted in Surat to prepare for flooding was the production of flood maps that did not previously exist for the city wards. In the next section we present flood simulations that were commissioned to understand the extent and magnitude of impact of different quantity of water released from the dam.

\subsection{Modelling}

30 Our modelling of flood in Surat featured two distinct hydrodynamic modelling stages. In stage one, we modelled dam release from the Ukai dam and the flow of water within the Tapi to the eastern boundary of Surat. Afterwards, the second stage of modelling used the outputs from stage one to drive a flood model of Surat that also included tidal effects on the river. In both modelling stages CAESAR-Lisflood models were used. CAESAR-Lisflood model is the outcome of merging the CAESAR 
Hydrol. Earth Syst. Sci. Discuss., doi:10.5194/hess-2016-544, 2016

landscape evolution model (Coulthard et al., 2013a) with the latest model version of Lisflood-FP (Bates et al., 2010). CAESAR-Lisflood is a storage cell model, where a DEM represents the landscape and water is stored at the raster cell locations. Water is routed over the landscape in two dimensions (2D) from raster cell to cell using a simplification of the shallow water equations (Bates et al., 2010). CAESAR-Lisflood is open source, has low computational demands, low data

5 requirements and has been used to replicate fluvial (Coulthard et al., 2013a, 2013b) and storm surge (Ramirez et al., 2016; Skinner et al., 2015) flooding. The model operates on inexpensive PC hardware, is parallelised to utilise multiple processor cores and is driven by a GUI front end making model set up and operation simpler. These model characterises make CAESARLisflood ideally suited for exploring the uncertainty in dam releases resulting from future climatic changes within the Tapi basin. We have developed dam release scenarios with different flood peak discharge and duration and estimate the resulting flood exposure within Surat.

For the first stage of modelling we developed a CAESAR-Lisflood hydrodynamic model at a spatial resolution of $30 \mathrm{~m}$ cell size (2.2 million raster cells), of the Tapi river from the Ukai dam to Surat (Fig. 1b). This DEM contains $79 \mathrm{~km}$ of the river length and nearly $15 \mathrm{~km}$ of floodplain on either side of the river. The hydrodynamic model uses topographic information 15 collected by the Shuttle Radar Topography Mission (SRTM) between February 11-22, 2000 (Jarvis et al., 2008). During this time the Tapi river was under low flow conditions (mean discharge $=129 \mathrm{~m}^{3} \mathrm{~s}^{-1}$ ) and the imaged river reach elevation values downstream from the Kakrapar weir sufficiently characterized the river channel (Fig. 1b). River channel elevation values upstream from the Kakrapar weir to the Ukai dam contained the elevation of the water level behind the weir. To better represent the river bed these elevations were replaced with values that were calculated using the bed slope $(m=0.0006)$ of the river downstream from the weir. Vegetation heights in the SRTM DEM can affect flood model results (Baugh et al., 2013; Wilson et al., 2007) but a 'Bare-Earth' SRTM DEM at $30 \mathrm{~m}$ resolution does not exist. Using a $90 \mathrm{~m}$ spatial resolution 'Bare-Earth' SRTM DEM (O'Loughlin et al., 2016) and the original $90 \mathrm{~m}$ SRTM DEM we estimated the mean vegetation height of our DEM was $1.3 \mathrm{~m}$. We concluded that vegetation effects would be minimal at our site and chose not to correct the DEM for these artefacts.

The flow of water between raster cells in CAESAR-Lisflood requires a roughness coefficient per cell (Manning's n) to represent landscape resistance. Throughout the river floodplain a $30 \mathrm{~m}$ spatial resolution land cover map (Yu et al., 2013) was acquired and roughness coefficients were applied to each land use class using values reported in Alfieri et al. (2014). Channel roughness was determined by calibrating the model using the September 22-26, 2013 Ukai dam release (Fig. 2a) that produced minimal amounts of flooding in Surat. For the calibration the modelled reach was extended $22 \mathrm{~km}$ downstream to the nearest gauging station which is not affected by tides (Singanpur weir (Fig. 1c)). Channel roughness values representing the sandy bed of the Tapi (Kale and Hire, 2004) were trialled (Manning's $n=0.01,0.02,0.03$ (Fisher and Dawson, 2003)) and the observed hydrograph recorded at the weir was reasonably replicated by the model using a channel roughness of 0.02 (Fig. 2a). 
Hydrol. Earth Syst. Sci. Discuss., doi:10.5194/hess-2016-544, 2016

Manuscript under review for journal Hydrol. Earth Syst. Sci.

Published: 18 November 2016

Using this channel roughness the root mean squared error between observed and modelled water levels at the weir was 0.39 m.

Synthetic Ukai dam outflows were based on the outflow of August 4-12, 2006 that produced catastrophic flooding in Surat. A

5 nonlinear regression was performed on this dam outflow time series to produce an idealized dam outflow at 10 min time steps (Fig. 2b). Multiplication factors were applied to the idealized dam outflow to produce synthetic dam outflows with all combinations of outflow durations $(2,3,4,5,6$ days) and estimated return periods $(5,10,25,50,100,250$ year) for the Tapi river (Rakhecha and Clark, 2002) (Fig. 2b). A total of 30 dam outflow scenarios were produced with each scenario consisting of two days of base flow $\left(2000 \mathrm{~m}^{3} \mathrm{~s}^{-1}\right)$ to develop initial hydraulic conditions, followed by a period of dam release, and

10 concluding with two days of base flow. For each scenario discharge arriving near Surat (western edge of the DEM) was collected every 10 minutes to produce a hydrograph that served as input into the second stage of modelling.

For the second stage of modelling a separate CAESAR-Lisflood hydrodynamic model was developed to estimate flooding within Surat. An accurate flood assessment of Surat required a representation of the bare earth that did not include the elevation

15 of urban infrastructure and vegetation heights. A high resolution DEM (e.g LIDAR quality) did not exist for the city so topographic data of the city was produced by undertaking an elevation survey of Surat using a differential global positioning system (DGPS). The city was intensively surveyed to acquire point elevations of hydrologically important topographic features that included streets, depressions, peaks, and river embankments. In total 6,219 point elevations were acquired during this ground survey with a horizontal accuracy of $\pm 30 \mathrm{~cm}$ and vertical accuracy of $\pm 30 \mathrm{~cm}$. Additionally, 172 river bed cross-

20 sections were obtained from the irrigation department to represent the river bed elevations. Outside of the city limits, where the survey was not preformed, elevation information was obtained from a $30 \mathrm{~m}$ SRTM DEM and converted into point vector GIS (Geographic Information System) format. Using DigitalGlobe high-resolution imagery (30 cm pixel size) locations surveyed consisting of bare ground or roads were used to determine the elevation difference between SRTM and survey data locations $(n=48)$. This vertical offset was applied to the survey data and transformed all the survey elevation values into the

25 SRTM vertical datum (EGM96). Survey points, river cross-sections and the surrounding SRTM values were interpolated together using the ordinary kriging method (ESRI ArcMap 9.3) to produce a high resolution DEM (30 m) of Surat, surrounding peri-urban areas and the Tapi river bed ( 1 million raster cells) (Fig. 1c). Overall this DEM encompasses an area of $835 \mathrm{~km}^{2}$ and contains $45 \mathrm{~km}$ of the Tapi river commencing near the eastern boundary of Surat and ending in the Arabian Sea. Channel roughness of the first modelling stage was also used in the hydrodynamic models of Surat $(n=0.02)$. We chose to represent

30 Surat's urban-fabric and the peri-urban areas with roughness values based on land cover classes (Alfieri et al., 2014) from a $30 \mathrm{~m}$ spatial resolution land cover map (Yu et al., 2013). Ideally we would have calibrated the roughness of the city and floodplain by replicating an observed flood extent, but this data does not exist for the DEM we have developed because embankments within the city have been raised and a major flood has not occurred since the construction of these embankments. 
Hydrol. Earth Syst. Sci. Discuss., doi:10.5194/hess-2016-544, 2016

Manuscript under review for journal Hydrol. Earth Syst. Sci.

Published: 18 November 2016

(c) Author(s) 2016. CC-BY 3.0 License.

Flood models of Surat were driven by 10 min temporal resolution discharge from the output from the first stage of modelling and this discharge was added to the upstream end of the Surat reach (Fig. 1c). Additionally, the effect of tides on the river was simultaneously modelled in all Surat flood simulations. Tidal fluctuations at Surat were modelled using the WebTide tidal prediction model (Dupont et al., 2002) that produces tidal heights for a particular time period using tidal harmonic constants

5 of major tidal constituents pre-calculated from a tidal ocean model. Tidal predictions of 5 min temporal resolution for Surat were calculated with WebTide for the years between 2010-2015 and monsoon months when emergency dam releases are more likely to occur (August, September and October). From this time series a subset spanning $240 \mathrm{hrs}$ (10 days) was extracted containing the maximum high tide of $3.1 \mathrm{~m}$ and a maximum tidal range of $5.9 \mathrm{~m}$. Tidal fluctuations were reproduced in the model by gradually raising and lowering water levels at two nearshore locations west of Surat (Fig. 1c) and this produced a

10 tide that advanced upstream the lower portion of the Tapi river. For each flood model maximum high tide coincided with peak discharge arriving at Surat and the combination of these factors produced worst-case flood conditions for the city. Each Surat flood model was set up using the same parameterization and tidal inputs, but the upstream dam release inputs were different. Model output per flood scenario consisted of a map of maximum flood water depths at each DEM location and this map also delineated the maximum flood extent for each flood scenario. Preliminary model flood maps were approved by municipality

15 flood experts, and this served as qualitative validation of the flood model extents and water depths.

In our study flood exposure was defined as the extent to which critical infrastructure, people, and income groups are geographically located in areas prone to deep flooding $(\geq 0.75 \mathrm{~m})$. We chose to analyse flood exposure at these depths because they result in extreme conditions that are threatening to life (waist deep water) and property (ground floor inundation) (World

20 Bank, 2011). Geographically our analysis of flood exposure included Surat and locations beyond the city limits. Herein we made a distinction between critical infrastructure that is related to transport and rescue/intervention and both datasets were analysed separately. Main roads and railroads comprised transport infrastructure, whilst fire stations, police stations, hospitals, and water tanks were regarded as rescue/intervention infrastructure (Fig. 3a). Locations of rescue/intervention infrastructure were mapped through questionnaire based field surveys using a global positioning system, whilst transport infrastructure was obtained from existing maps. Exposure to people was made using a map of spatially distributed population estimates from 2015 (Fig. 3b) at the spatial resolution of $100 \mathrm{~m}^{2}$ (Gaughan et al., 2013). Lastly, we investigated the relationship between flood exposure and monetary income using a map of neighbourhoods with different income levels (Fig. 3c). Income groups were mapped through a detailed physical survey which was conducted over 100 transects across the city and questionnaire based survey conducted across 400 households along these transects to capture their capacity and vulnerability information. A geo-

30 location and building typology based association technique was used to spatially identify areas which are similar to the 100 transects based on their proximity to the surveyed sample and physical characteristics. Land use polygons within the neighbourhood having similar characteristics were assigned similar rankings. Flood exposure analysis was performed using the modelled Surat maximum water depth maps resulting from each of the 30 dam release scenarios with different return 
Hydrol. Earth Syst. Sci. Discuss., doi:10.5194/hess-2016-544, 2016

Manuscript under review for journal Hydrol. Earth Syst. Sci.

Published: 18 November 2016

(c) Author(s) 2016. CC-BY 3.0 License.

periods and flood duration. These flood maps were spatially overlaid on the maps of critical infrastructure, population and income group, and the percentage of each metric at each location with inundation $\geq 0.75 \mathrm{~m}$ was calculated.

A disaster management cycle for flood hazard summarizes processes and actions taken by government, businesses and the

5 community to reduce the consequences of flooding. Disaster management cycles include phases for mitigation, preparedness, response, and recovery (Keiler et al., 2010; Vasilescu et al., 2008). Mitigation minimizes the effect of flooding and may include raising community awareness about floods or constructing flood protection measures. Preparedness involves the development of plans to respond to flooding and may include the implementation and operation of a flood early warning system. The response phase encompasses actions taken after a flood event to reduce the effects of flooding on the community and consists

10 of rescue efforts and the delivery of aid. A recovery phase is an extended period after the event where the community rebuilds. We use this disaster management cycle to identify phases where our modelling has made tangible contributions to flood risk reduction and resilience building after the 2006 Surat flood.

\section{Results}

Figure 4 are dam outflows and the resulting city flood hydrographs produced by the dam outflow model (model stage 1). In

15 all of the simulations a quantity of the dam outflow was lost to the topographically flat, expansive, floodplain between the Ukai dam and Surat and this attenuated/distorted the rising limb of the resulting flood hydrograph. Overall this section of river acted as a buffer or store that reduced the amount of water arriving in the city by $1-4 \%$. The buffering capacity of the floodplain was greatest when dam out flows were high and of long duration, and these conditions resulted in extensive amounts of flooding on either side of the river. An important result from the modelled dam outflow was the duration of time required for the flood

20 to crest the embankments after a dam release. Embankments in the city were constructed to contain floods of $17,000 \mathrm{~m}^{3} \mathrm{~s}^{-1}$ and it was assumed that discharge greater than this would produce flooding within the city. Using this flood threshold, on average all modelled dam releases flooded the city between 10-14 hrs (average $=11 \mathrm{hrs}$ ). This information provides the minimum amount of flood warning that can be given to the city inhabitants after a dam release has been performed. Furthermore, all model runs indicated that after maximum dam outflow between 14-33 hrs (average $=26 \mathrm{hrs}$ ) elapsed before maximal discharge conditions occurred near Surat. This time lag was greatest for dam release scenarios with combined long durations and high peak discharges.

Figure 5 are maps produced by the city flood model (model stage 2) and represent maximum flood depths and spatial extents for a subset of the flood scenarios. Here it can be determined that changes in flood return period (Fig. $5 \mathrm{a}, \mathrm{d}, \mathrm{g}$ ) caused greater 30 amounts of flooding (extent and depths) than increases in flood duration (Fig. 5 g,h,i). It is apparent that the city levees are effective at preventing flooding at the lowest return period (1:5 yr), but limited amounts of flooding still occurred in the west part of the city (Fig. 5 g,h,i). Levees are less effective at containing floodwaters at return periods $\geq 50$ yrs, with extensive 
Hydrol. Earth Syst. Sci. Discuss., doi:10.5194/hess-2016-544, 2016

Manuscript under review for journal Hydrol. Earth Syst. Sci.

Published: 18 November 2016

(c) Author(s) 2016. CC-BY 3.0 License.

amounts of flooding in the city and peri-urban area. The worst case scenario of a 1:250 yr flood lasting six days resulted in $50 \%$ of the study being flooded (Fig. 5c) and nearly all of the flood depths were considered deep ( $\geq 0.75 \mathrm{~m}$ ). Large flood extents and deep water depths do not always translate in to high levels of exposure unless flooding spatially coincides with critical infrastructure and residential locations. Figure 6 illustrates that an overall increase in flood return period results in greater exposure than increases in flood duration. For each sector analysed exposure continues to be elevated (28-48\%) for a flood equivalent to the catastrophic 2006 flood event (1:25 yr return period, 5 day duration), regardless of the construction of new embankments. Specifically, reoccurrence of the 2006 event would flood (water depths $\geq 0.75 \mathrm{~m}$ ) $29 \%$ of the city's population ( 713,000 people), $29 \%$ of the transportation network, and $37 \%$ of the hospitals, police/fire stations, and water tanks. Rare, but plausible, extreme events (1:250 yr return period, flood duration of 6 days) shockingly inundated $60 \%$ of the 10 population ( 1.5 million people), $60 \%$ of the rescue/intervention, and $60 \%$ of the transportation network. Unexpectedly, the newly constructed flood protection does not eliminate flooding and exposure from low return period events (1:5 yr, 2-4 days duration). For example, the smallest flood modelled (1:5 yr, 2 day duration) can potentially expose $\sim 100,000$ people to deep flooding. Regarding exposure and income level (Fig. 6 d,e,f), model results suggested that low income communities are less exposed than, moderate and high income communities.

15

Using the disaster management cycle (mitigation, preparedness, response, and recovery) our flood maps and exposure assessment contributed to several phases reducing flood risk reduction in Surat. Within the mitigation phase our flood maps and exposure assessment have contributed to the reduction of the impact of flooding by instigating changes within the operational protocols of the urban local body and attitudinal change amongst the citizens especially the vulnerable population.

20 The floods maps are currently being used to strengthen the city disaster management plan and resource allocation during monsoon preparedness. The results from the flood model were also used for demarcating possible flood depths on public lamp posts across the city (Fig. 7). The demarcation raised awareness of flooding by providing information to people on the extent of inundation for specific quantities and durations of water released from the dam. This flood depth information is particularly important to Surat's immigrants, which comprises the majority of the population. Between 2001 and 2011 the city's population increased by over 70\% (India, 2011) due to pull migration, where people come to the city from both within the state of Gujarat and from other states such as Bihar and Odisha in search of employment. Many of these immigrants who come to the city choose residences in areas which are more vulnerable to flooding. Such choice is usually influenced by the cost and rarely is information on flood levels at these locations available. The painting of lamp posts throughout the city with potential flood heights from the model provides dual benefits to the citizens. Firstly, migrants and visitors to the city will be aware of areas

30 which are prone to the floods. Thereby they will make informed decisions while choosing their place of residence. Since the implementation of the painted lamp posts this has already started impacting the real estate within the city. Many people now are re-considering their choice to invest in buildings which are highly vulnerable to the floods. Secondly, the marking also act as communication posts during an event. The markings help people internalize the technical information which are disseminated during the event by the different government agencies. For example, if a dam release occurs for a specific return 
Hydrol. Earth Syst. Sci. Discuss., doi:10.5194/hess-2016-544, 2016

period, any resident can look at the lamp post near their residence and get information on the extent of inundation which is likely to occur in the surroundings. Contextualized information provided to different communities across the city will not only help citizens prepare for the flood hazard but will also help others in low risk zones to remain calm. This leads to less city wide panic, reduced traffic congestion and reduced social unrest before the event. In addition to the painted lamp posts, flood maps

5 produced by the model are currently being used by Municipal Corporation engineers and their ward level representatives for their monsoon preparedness activities which includes public awareness program on flood risk reduction.

Within the preparedness phase flood maps generated from the model are being used for preparing flood risk management plans that include: 1) highlighting key locations for helicopters to drop food and medical supplies, 2) locate health care units

10 which may require evacuation in case of flooding, 3) identify buildings which are to be used as safe shelters, 4) determine critical infrastructure that needs to be protected and 5) more importantly identification of vulnerable locations where there will be a need for prioritized communication for evacuation. The flood maps are currently being used as a part of a larger End to Early warning system which was established under the Asian Cities Climate Change Resilience Network (ACCCRN) and currently being maintained by the Surat Municipal Corporation and Surat Climate Change Trust. Shortly after a dam release,

15 within the response phase, the exposure information will provide city officials with an overall estimate of population and infrastructure that are likely to be affected by flooding. The depth of the flooding as modeled using multiple simulations will help them in prioritizing their response actions. Usually high priority is given to slums (informal and formal settlements) where the water depth will be more than $2 \mathrm{~m}$. Also all other settlements including middle income and high income communities are informed through public address system to initiate evacuation. Previously, there used be a city wide announcement of warning

20 and alerts followed by deployment of resources across all areas based on the administrative boundaries. With the help of the flood maps, the city government can provide contextual warning and allocate their resources on select areas depending upon the extent of the possible impact. Additionally modelled flood maps will be used to locate communities that require immediate evacuation. During the recovery phase model output is not useful, instead resource allocation usually happens post field investigation of actual damage.

\section{Discussion}

Our modelling approach used a 2D hydrodynamic model to estimate the quantity and velocity of water arriving at Surat and represents an improvement over previous studies investigating flooding in Surat using one dimensional (1D) approaches (Timbadiya et al., 2014a, 2014b). While 1D models can adequately predict water levels that are confined to a river channel, a 1D model's performance deteriorates when water spreads onto the floodplain and flow becomes $2 \mathrm{D}$. As such, our 2D 30 implementation provides an advantage over 1D models by better replicating the important process whereby flood wave attenuation, loss of water, occurs from the dam to the city when water spreads onto the floodplain (Fig. 4). Further improvements can be made to our models by including processes that replicate infiltration to the floodplain subsurface. In our 
Hydrol. Earth Syst. Sci. Discuss., doi:10.5194/hess-2016-544, 2016

simulations flood discharge conveyed across the floodplain accounted for a loss of 1-4\% of the water arriving in Surat, but these values are more than likely conservative losses of water because infiltration was not modelled. As such greater flood attenuation and less flooding in Surat could be attained with a model that accounts for infiltration occurring on the floodplain. Regarding flow velocity, our model was able to replicate well the amount of time it takes for flooding to commence in Surat

5 after a major dam release $\left(>17,000 \mathrm{~m}^{3} \mathrm{~s}^{-1}\right)$. For example, during the 2006 flood the dam release flood wave took approximately $10 \mathrm{hrs}$ to arrive in Surat, and our model estimated $12 \mathrm{hrs}$ for a dam release of similar peak discharge and duration.

Uncertainty in the flood maps produced by CAESAR-Lisflood could be traced back to error in data sources and model processes. The principal source of uncertainty in CEASAR-Lisflood's output is produced by error in the topographic data that

10 subsequently affects the flood wave movement. For example the smallest elevation error, obstruction, or artefact in the DEM could divert water to locations that do not experience flooding. In our city flood model topographic error was minimized by not using a DEM that contained land features (buildings and vegetation), but instead, a bare surface representation of the city was developed from a high resolution ground survey. We find that this method of generating a bare surface DEM is effective for urban environments where LIDAR quality topographic data is not available or feasible. Although the DEM created is of

15 superior quality (vertical and horizontal accuracy) than the commonly used $30 \mathrm{~m}$ SRTM DEM, more extensive surveying is needed to achieve greater spatial resolution $(<10 \mathrm{~m})$. Of particular importance is the need to accurately represent the city embankments within the DEM and model output suggests that embankments were adequately represented in the DEM because all city models do not commence breaching embankments until discharge exceeds the established flood warning level for the city $\left(\sim 17,000 \mathrm{~m}^{3} \mathrm{~s}^{-1}\right)$.

A secondary factor producing uncertainty in the city model output is error in surface friction values that were used to represent the restriction of flow over land features. Although the finest spatial resolution $(30 \mathrm{~m})$ land cover data available was used to infer surface friction values for Surat, it is possible that classification error in the land cover resulted in incorrect setting of some surface friction values. Ideally channel roughness for this model would be calibrated, but observed flood extents and water depths do not exist to calibrate the floodplain friction for the city. These data are not available because no major flood has occurred since the construction of the embankments. Regardless, in order to partially account for the uncertainty in floodplain friction and resulting spatial extent of flooding we present 30 possible dam release driven floods. Additional uncertainty in model output can result from physical processes that are not developed within CAESAR-Lisflood. Several of these processes include infiltration and storm drains. These additional model processes may reduce the amount of flooding

30 within the city, but their implementation would require significant model development (e.g. groundwater interactions) that is beyond the scope of this study.

High levels of flood exposure at low return periods (1:10 yr) for rescue and intervention infrastructure can be explained by the locations of hospitals and police stations which are proximate to the river channel $(<2 \mathrm{~km})$ at locations where embankments 
Hydrol. Earth Syst. Sci. Discuss., doi:10.5194/hess-2016-544, 2016

first breach and flood the city. Likewise high exposure of population with relatively small floods can be explained by higher population densities ( 230 people/100 $\mathrm{m}^{2}$ ) near the breaching of levees within the core of the city. Our results suggest that low income neighbourhoods have less exposure than high and middle income neighbourhoods. For example, low income groups are highly exposed (> 40\%) to deep flooding when dam releases approach return periods $>1: 50 \mathrm{yr}$, while similar exposure is

5 experienced by high and middle income groups with return $>1: 25 \mathrm{yr}$. Lower exposure to low income groups is explained by the locations of these neighbourhoods in the floodplain which are distant to the channel in comparison to high and middle income neighbourhoods. Although our assessment suggests that low income groups have lower exposure to deep flooding it is important to highlight that these groups are most vulnerable to flood disasters. For example, in Surat few low income groups have flood insurance and $75 \%$ of low income groups have employment that results in income instability after a flood disaster

10 due to damage to industry and disruption to production (Bhat et al., 2013; Jha et al., 2012). While our flood exposure assessment takes into account potential changes in climate and resulting floods, the model does not consider socio-economic changes (e.g. population dynamics, land use change) in Surat. As such the exposure results presented here are current estimates of exposure and future exposure estimates will require model development that considers interactions between biophysical and socio-economic factors (e.g. land use change) affecting flood exposure and vulnerability in urban areas.

15

The modelled flood maps are currently being used by the urban local body within their monsoon preparedness activities and city disaster management plan. During an event, the maps will be used for providing contextual warning to the communities based on their risk profile. Also poor and vulnerable communities which are at relatively high risk can be prioritised for evacuation. During the disaster, the maps will help in identifying helicopter drop locations for food and medical supplies. The lamp post marking based on flood inundation maps have created large scale awareness amongst the communities. The flood maps are currently part of the end to end early warning system established in Surat. The dam release information (alerts) can now be used by the citizens to contextualize their action plans based on the possible level of inundation for a given release as indicated within the markings on the lamp post. During time periods without flooding, citizens especially the migrants can use this information before they choose to buy real estate or choose to relocate to a new neighbourhood. This action over time will indirectly affect the value of the real estate developments in flood plains and thereby influencing the local economy to move towards risk informed development.

\section{Conclusion}

This study demonstrates how an inexpensive reduced-complexity modelling approach can be used to map flooding and flood

30 exposure in large urban areas. The flood model demonstrates how the combined low computational overhead and low data requirements of CAESAR-Lisflood enabled the generation of the first flood maps for Surat that explore the uncertainty in flood peak discharge and duration resulting from possible climate change. These scenarios include catastrophic conditions that flood $50 \%$ of the city and expose $>60 \%$ of the population and critical infrastructure to deep flooding. Overall, modelled floods and exposure estimates demonstrate the ineffectiveness of the new embankments to protect the city from flooding as low return 
Hydrol. Earth Syst. Sci. Discuss., doi:10.5194/hess-2016-544, 2016

Manuscript under review for journal Hydrol. Earth Syst. Sci.

Published: 18 November 2016

period and duration floods are not entirely contained. Within this study flood exposure estimated for the city's critical infrastructure and population provides a synoptic view of potential exposure to deep flooding resulting from dam releases scenarios. In Surat we found that flood maps and exposure estimates were applied within the phases of the risk management cycle and was strongly supported by decision makers that were willing to address the problem of flooding and invest in

5 resilience building for the city. The local government used information produced by models to adapt and develop risk reduction and resilience building strategies for flood risk with low-cost measures.

Acknowledgements. This paper is a part of larger project titled "Establishment of End to End Early Warning System in Surat". We would like to thank Asian Cities Climate Change Resilience Network (ACCCRN) and Rockefeller foundation for funding

10 the study. Our gratitude to Surat Municipal Corporation and Surat Climate Change Trust (SCCT) for their support in execution and mainstreaming the modelling results as a part of their flood preparedness. Special thanks to the project team comprising of G. K. Bhat, Lalit Dashora, Tejas Patel, Noor Hassan, Mehul Patel and Hardik Prajapati. This project was supported by the University of Bern, Institute of Geography, Risk and Resilience Cluster.

\section{References}

15 Alfieri, L., Salamon, P., Bianchi, A., Neal, J., Bates, P. and Feyen, L.: Advances in pan-European flood hazard mapping, Hydrol. Process., 28(13), 4067-4077, doi:10.1002/hyp.9947, 2014.

Baldassarre, G. Di, Viglione, A., Carr, G., Kuil, L., Salinas, J. L. and Blöschl, G.: Socio-hydrology: conceptualising humanflood interactions, Hydrol. Earth Syst. Sci., 17(8), 3295-3303, 2013.

Di Baldassarre, G., Viglione, A., Carr, G., Kuil, L., Yan, K., Brandimarte, L. and Blöschl, G.: Debates-Perspectives on socio-

20 hydrology: Capturing feedbacks between physical and social processes, Water Resour. Res., 51(6), 4770-4781, 2015.

Bates, P. D., Horritt, M. S. and Fewtrell, T. J.: A simple inertial formulation of the shallow water equations for efficient twodimensional flood inundation modelling, J. Hydrol., 387(1-2), 33-45, doi:http://dx.doi.org/10.1016/j.jhydrol.2010.03.027, 2010.

Baugh, C. A., Bates, P. D., Schumann, G. and Trigg, M. A.: SRTM vegetation removal and hydrodynamic modeling accuracy, 25 Water Resour. Res., 49(9), 5276-5289, 2013.

Bhat, G. K., Karanth, A., Dashora, L. and Rajasekar, U.: Addressing flooding in the city of Surat beyond its boundaries, Environ. Urban., 0956247813495002, 2013.

Birkmann, J., Cardona, O. D., Carreño, M. L., Barbat, A. H., Pelling, M., Schneiderbauer, S., Kienberger, S., Keiler, M., Alexander, D., Zeil, P. and others: Framing vulnerability, risk and societal responses: the MOVE framework, Nat. hazards, 30 67(2), 193-211, 2013.

Coulthard, T. J., Neal, J. C., Bates, P. D., Ramirez, J., de Almeida, G. A. M. and Hancock, G. R.: Integrating the LISFLOODFP 2D hydrodynamic model with the CAESAR model: implications for modelling landscape evolution, Earth Surf. Process. 
Hydrol. Earth Syst. Sci. Discuss., doi:10.5194/hess-2016-544, 2016

Manuscript under review for journal Hydrol. Earth Syst. Sci.

Landforms, 38(15), 1897-1906, doi:10.1002/esp.3478, 2013a.

Coulthard, T. J., Ramirez, J. A., Barton, N., Rogerson, M. and Brücher, T.: Were Rivers Flowing across the Sahara During the Last Interglacial? Implications for Human Migration through Africa, PLoS One, 8(9), e74834 [online] Available from: http://dx.doi.org/10.1371/journal.pone.0074834, 2013b.

5 Deshpande, N. R., Kothawale, D. R. and Kulkarni, A.: Changes in climate extremes over major river basins of India, Int. J. Climatol., 2016.

Dupont, F., Hannah, C. G., Greenberg, D. A., Cherniawsky, J. Y. and Naimie, C. E.: Modelling system for tides for the Northwest Atlantic coastal ocean, Fisheries and Oceans Canada., 2002.

Fewtrell, T. J., Neal, J. C., Bates, P. D. and Harrison, P. J.: Geometric and structural river channel complexity and the prediction 10 of urban inundation, Hydrol. Process., 25(20), 3173-3186, doi:10.1002/hyp.8035, 2011.

Fisher, K. and Dawson, H.: Reducing uncertainty in river flood conveyance, Rough. Rev. Proj. W5A-057. DEFRA/Environment Agency, 2003.

Gaughan, A. E., Stevens, F. R., Linard, C., Jia, P. and Tatem, A. J.: High Resolution Population Distribution Maps for Southeast Asia in 2010 and 2015, PLoS One, 8(2), e55882, doi:10.1371/journal.pone.0055882, 2013.

15 Güneralp, B., Güneralp, I.Inci and Liu, Y.: Changing global patterns of urban exposure to flood and drought hazards, Glob. Environ. Chang., 31, 217-225, 2015.

India, R. G.: Census of India, 2011, India, Provisional Popul. Total. Pap., 1, 2011.

Jarvis, A., Reuter, H. I., Nelson, A. and Guevara, E.: Hole-filled seamless SRTM data V4, Int. Cent. Trop. Agric., 2008.

Jha, A. K., Bloch, R. and Lamond, J.: Cities and flooding: a guide to integrated urban flood risk management for the 21st 20 century, World Bank Publications., 2012.

Jongman, B., Ward, P. J. and Aerts, J. C. J. H.: Global exposure to river and coastal flooding: Long term trends and changes, Glob. Environ. Chang., 22(4), 823-835, 2012.

Kale, V. S. and Hire, P. S.: Effectiveness of monsoon floods on the Tapi River, India: role of channel geometry and hydrologic regime, Geomorphology, 57(3-4), 275-291, doi:http://dx.doi.org/10.1016/S0169-555X(03)00107-7, 2004.

25 Keiler, M., Knight, J. and Harrison, S.: Climate change and geomorphological hazards in the eastern European Alps, Philos. Trans. R. Soc. London A Math. Phys. Eng. Sci., 368(1919), 2461-2479, 2010.

Mishra, V. and Lilhare, R.: Hydrologic sensitivity of Indian sub-continental river basins to climate change, Glob. Planet. Change, 139, 78-96, doi:http://dx.doi.org/10.1016/j.gloplacha.2016.01.003, 2016.

Misra, A. and Balaji, R.: Decadal changes in the land use/land cover and shoreline along the coastal districts of southern

30 Gujarat, India, Environ. Monit. Assess., 187(7), 1-13, 2015.

National Disaster Management Authority: Management of floods: national disaster management guidelines. [online] Available from: http://www.ndma.gov.in/images/guidelines/flood.pdf, 2008.

O’Loughlin, F. E., Paiva, R. C. D., Durand, M., Alsdorf, D. E. and Bates, P. D.: A multi-sensor approach towards a global vegetation corrected SRTM DEM product, Remote Sens. Environ., 182, 49-59, 
Hydrol. Earth Syst. Sci. Discuss., doi:10.5194/hess-2016-544, 2016

Manuscript under review for journal Hydrol. Earth Syst. Sci.

Published: 18 November 2016

doi:http://dx.doi.org/10.1016/j.rse.2016.04.018, 2016.

Patel, D. P. and Srivastava, P. K.: Flood hazards mitigation analysis using remote sensing and GIS: correspondence with town planning scheme, Water Resour. Manag., 27(7), 2353-2368, 2013.

Rakhecha, P. R. and Clark, C.: The probable maximum flood at the Ukai and Lakhwar dam sites in India, in The Extremes of

the Extremes: Extraordinary Floods, edited by A. Snorrason, H. P. Finnsdottir, and M. E. Moss, p. 283, International Assn of Hydrological Sciences., 2002.

Ramirez, J. A., Lichter, M., Coulthard, T. J. and Skinner, C.: Hyper-resolution mapping of regional storm surge and tide flooding: comparison of static and dynamic models, Nat. Hazards, 82(1), 571-590, doi:10.1007/s11069-016-2198-z, 2016.

Sampson, C. C., Fewtrell, T. J., O’Loughlin, F., Pappenberger, F., Bates, P. B., Freer, J. E. and Cloke, H. L.: The impact of

10 uncertain precipitation data on insurance loss estimates using a flood catastrophe model, Hydrol. Earth Syst. Sci., 18(6), 23052324, doi:10.5194/hess-18-2305-2014, 2014.

Seto, K. C., Fragkias, M., Güneralp, B. and Reilly, M. K.: A meta-analysis of global urban land expansion, PLoS One, 6(8), e23777, 2011.

Skinner, C. J., Coulthard, T. J., Parsons, D. R., Ramirez, J. A., Mullen, L. and Manson, S.: Simulating tidal and storm surge

15 hydraulics with a simple 2D inertia based model, in the Humber Estuary, U.K, Estuar. Coast. Shelf Sci., (0), -, doi:http://dx.doi.org/10.1016/j.ecss.2015.01.019, 2015.

Timbadiya, P. V, Patel, P. L. and Porey, P. D.: A 1D--2D Coupled Hydrodynamic Model for River Flood Prediction in a Coastal Urban Floodplain, J. Hydrol. Eng., 20(2), 5014017, 2014a.

Timbadiya, P. V, Patel, P. L. and Porey, P. D.: One-dimensional hydrodynamic modelling of flooding and stage hydrographs

20 in the lower Tapi River in India, Curr. Sci., 105(5), 708-716, 2014b.

United Nations: World Urbanization Prospects: The 2014 Revision., 2015.

Vasilescu, L., Khan, A., Khan, H. and others: Disaster management cycle--a theoretical approach, Manag. Mark., (1), 43-50, 2008.

Wilson, M., Bates, P., Alsdorf, D., Forsberg, B., Horritt, M., Melack, J., Frappart, F. and Famiglietti, J.: Modeling large-scale inundation of Amazonian seasonally flooded wetlands, Geophys. Res. Lett., 34(15), n/a-n/a, doi:10.1029/2007GL030156, 2007.

Wohl, E., Lane, S. N. and Wilcox, A. C.: The science and practice of river restoration, Water Resour. Res., 51(8), 5974-5997, 2015.

World Bank: India Vulnerability of Kolkata Metropolitan Area to Increased Precipitation in a Changing Climate. [online]

30 Available from: https://openknowledge.worldbank.org/handle/10986/2818, 2011.

Yu, L., Wang, J. and Gong, P.: Improving $30 \mathrm{~m}$ global land-cover map FROM-GLC with time series MODIS and auxiliary data sets: a segmentation-based approach, Int. J. Remote Sens., 34(16), 5851-5867, doi:10.1080/01431161.2013.798055, 2013. 
Hydrol. Earth Syst. Sci. Discuss., doi:10.5194/hess-2016-544, 2016

Manuscript under review for journal Hydrol. Earth Syst. Sci.

Published: 18 November 2016

(c) Author(s) 2016. CC-BY 3.0 License.
Hydrology and

Earth System

Sciences

Discussions

(c) (i)

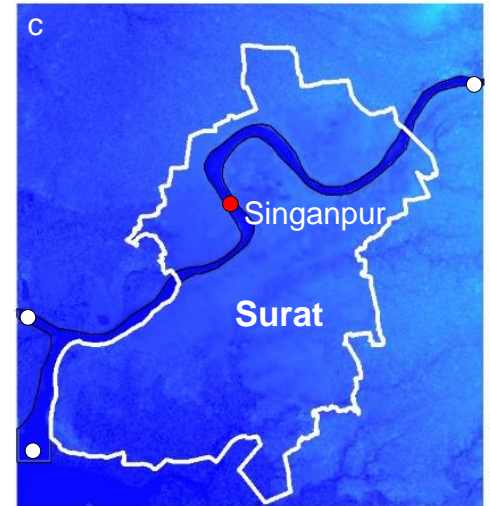

Elevation $(\mathrm{m}) \quad \mathrm{\text {waterinputs }}$ 341

$-13$
- weir

- dam

$\square$ city limit
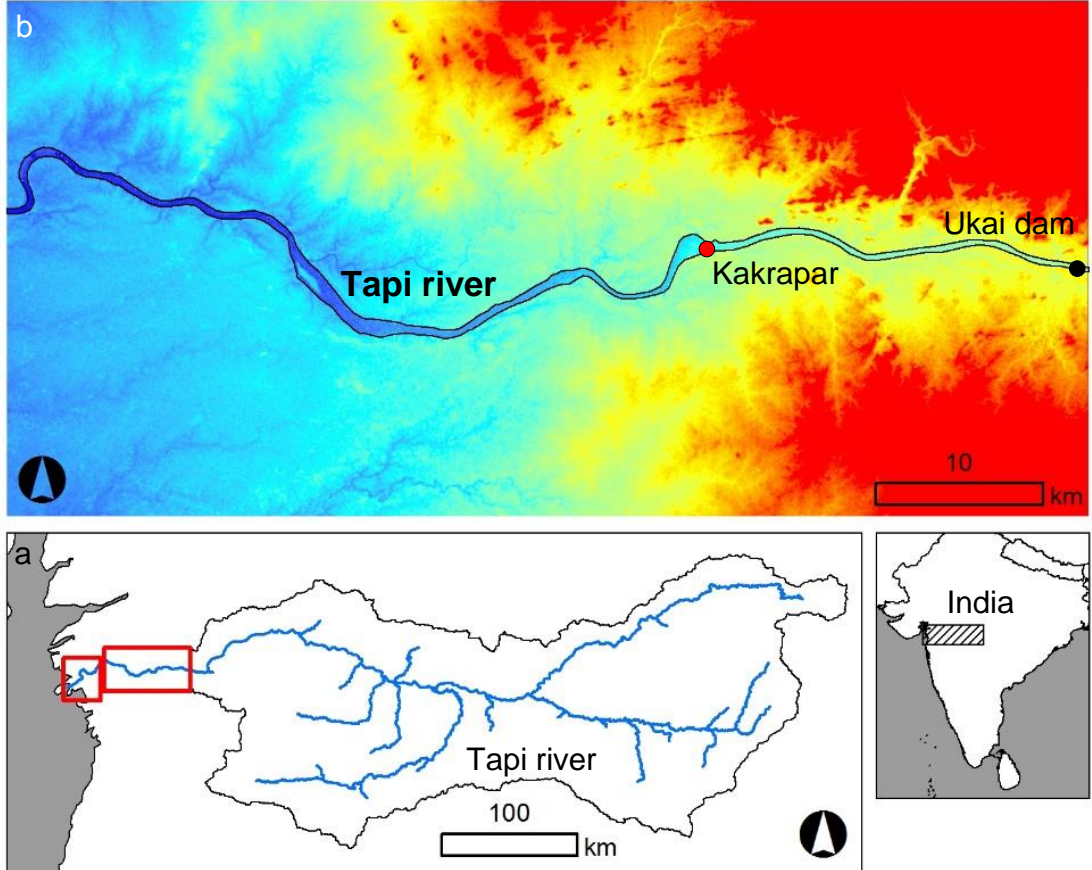

$\boldsymbol{\Delta}$

Figure 1: (a) Tapi river catchment and extent of stage one and stage two models (in red). (b) DEM of Tapi river from the Ukai dam to Surat and (c) DEM of Surat. Location of Tapi catchment and study area within India (inset). 
Hydrol. Earth Syst. Sci. Discuss., doi:10.5194/hess-2016-544, 2016

Manuscript under review for journal Hydrol. Earth Syst. Sci.

Published: 18 November 2016

(c) Author(s) 2016. CC-BY 3.0 License.

\section{(c) (1)}

Hydrology and

Discussions
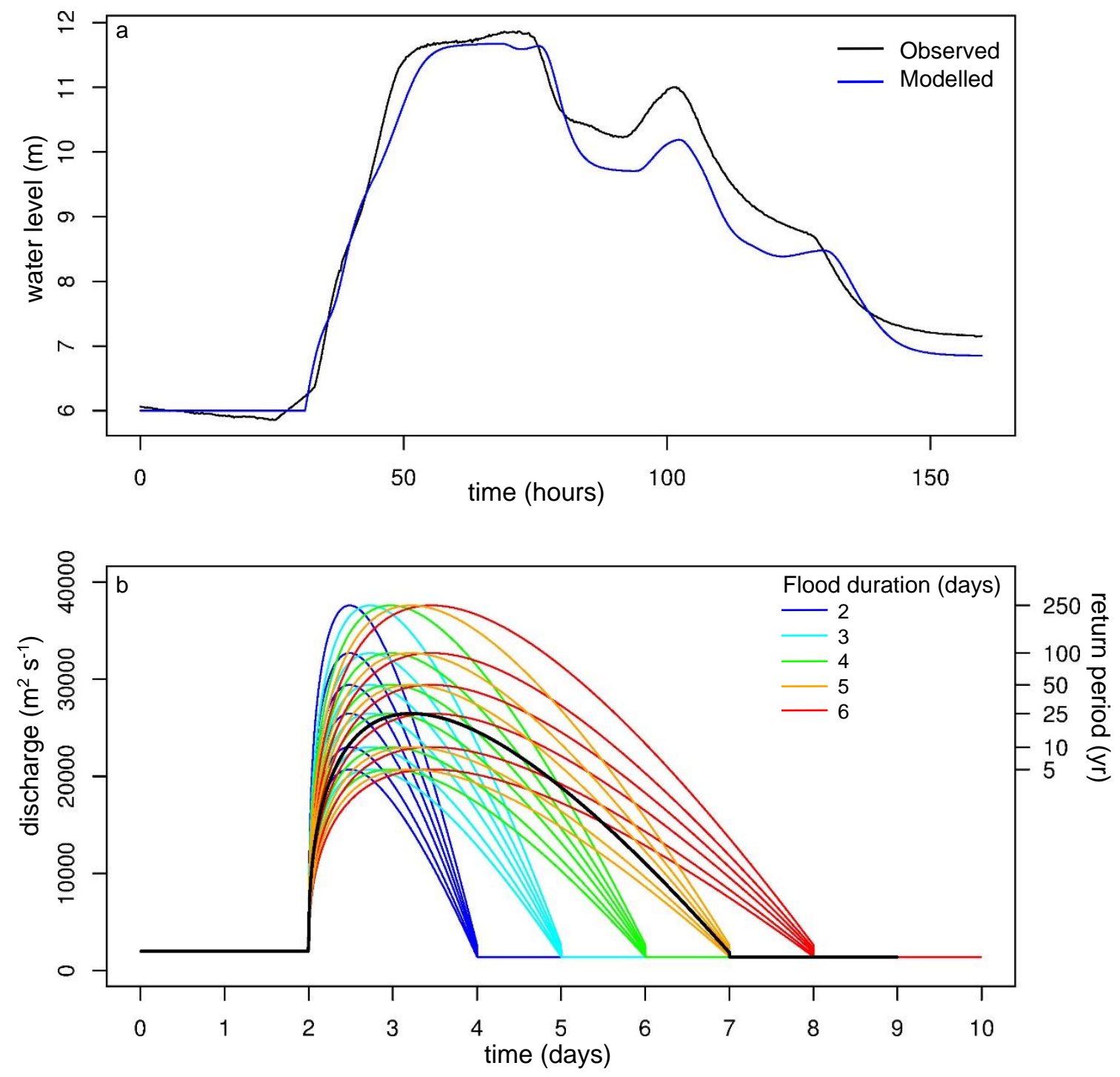

Figure 2: (a) Observed and modelled hydrograph at Singanpur weir. (b) Synthetic Ukai dam outflows and idealized 2006 flood (in black). 
Hydrol. Earth Syst. Sci. Discuss., doi:10.5194/hess-2016-544, 2016

Manuscript under review for journal Hydrol. Earth Syst. Sci.

Published: 18 November 2016

(c) Author(s) 2016. CC-BY 3.0 License.

(c) (i)

\section{Hydrology and \\ Earth System \\ Sciences \\ Discussions}
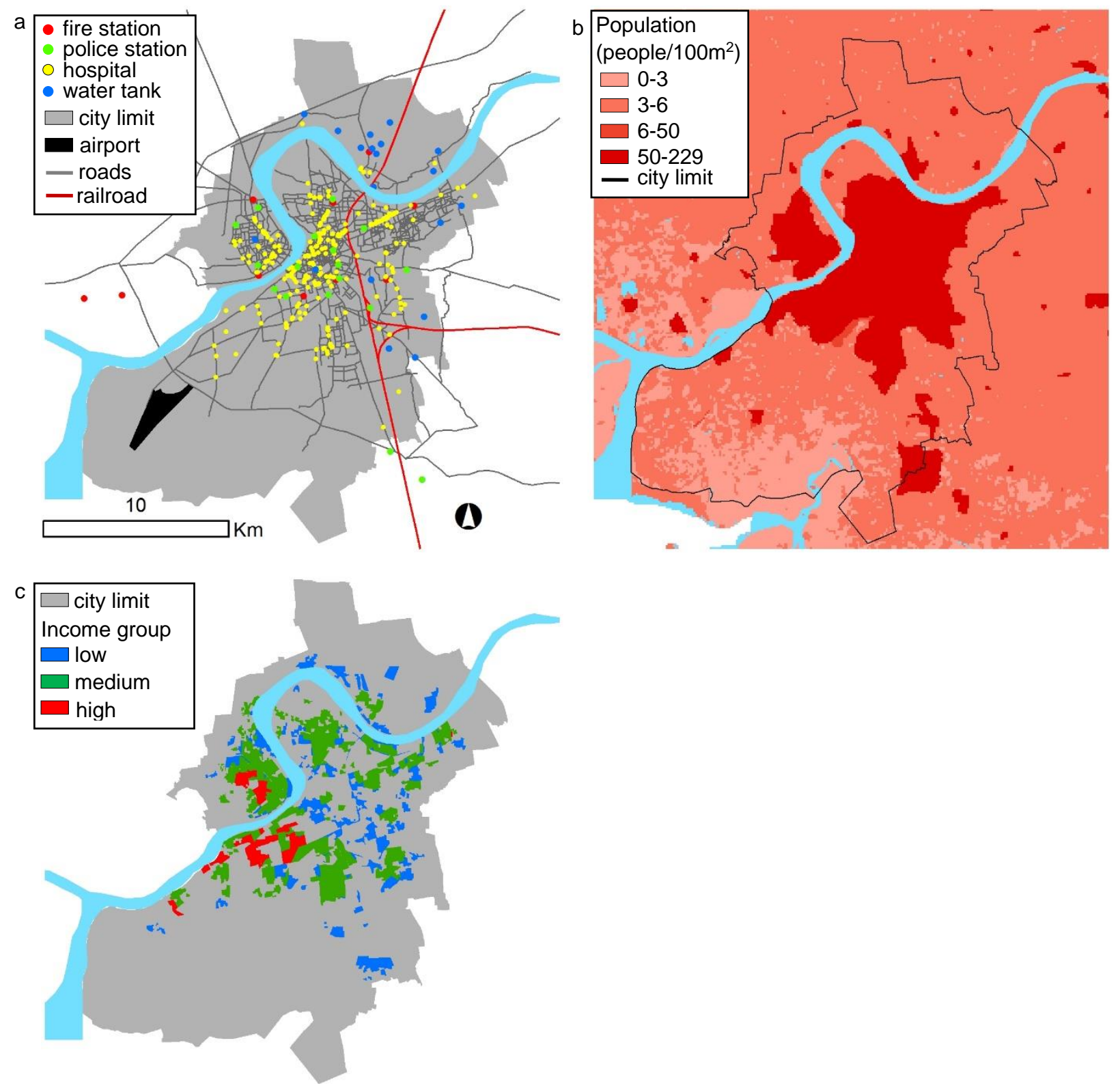

Figure 3: Surat (a) critical infrastructure, (b) population, and (c) income groups (all maps at same scale). 
Hydrol. Earth Syst. Sci. Discuss., doi:10.5194/hess-2016-544, 2016

Manuscript under review for journal Hydrol. Earth Syst. Sci.

Published: 18 November 2016

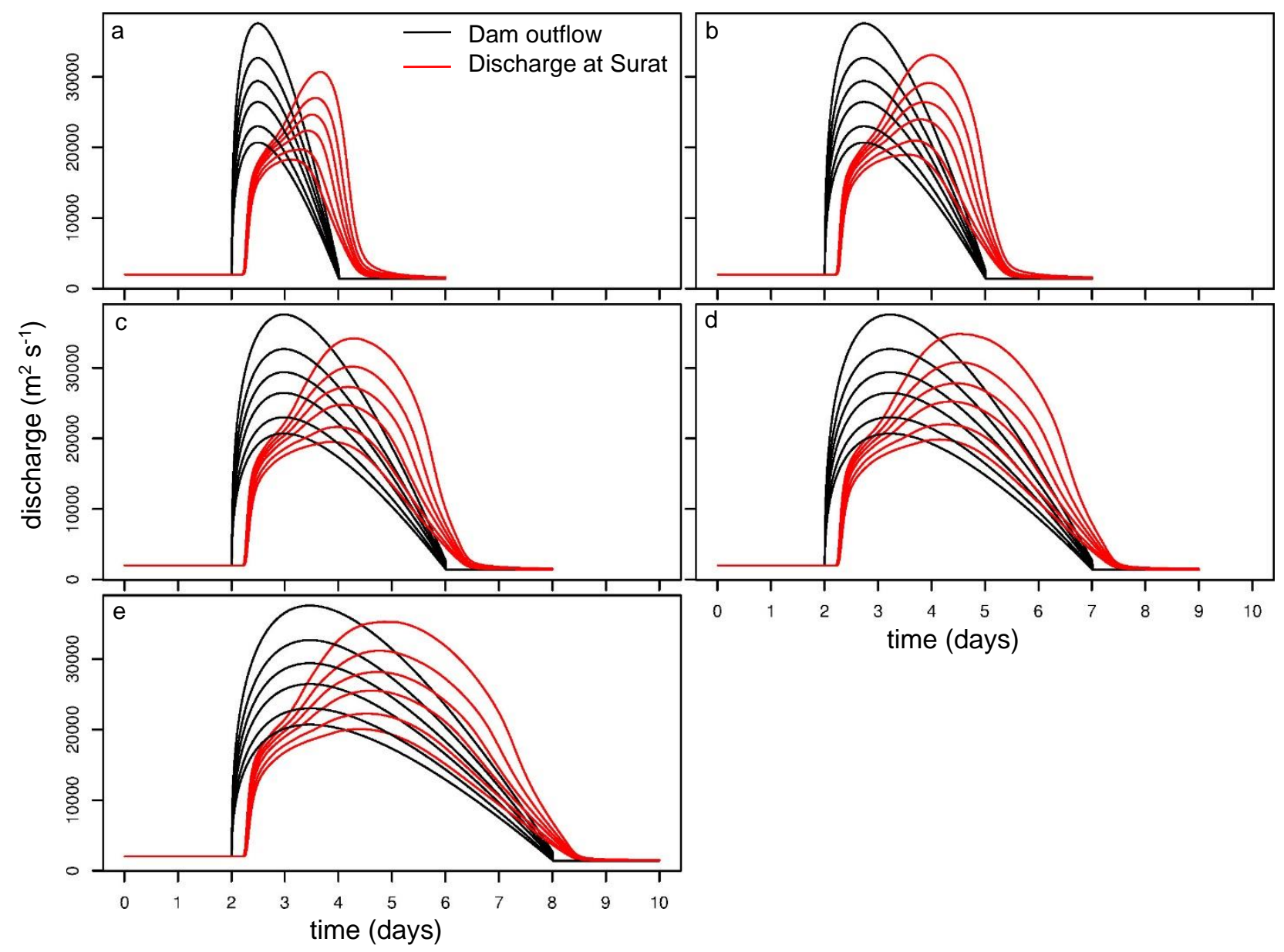

Figure 4: (a) Ukai dam outflows (in black) and discharge arriving at Surat (in red) for floods with durations of (a) 2, (b) 3, (c) 4, (d) 5, (e) 6 days. 
Hydrol. Earth Syst. Sci. Discuss., doi:10.5194/hess-2016-544, 2016 Manuscript under review for journal Hydrol. Earth Syst. Sci.

Published: 18 November 2016

(c) Author(s) 2016. CC-BY 3.0 License.
Hydrology and

Earth System

Sciences

Discussions
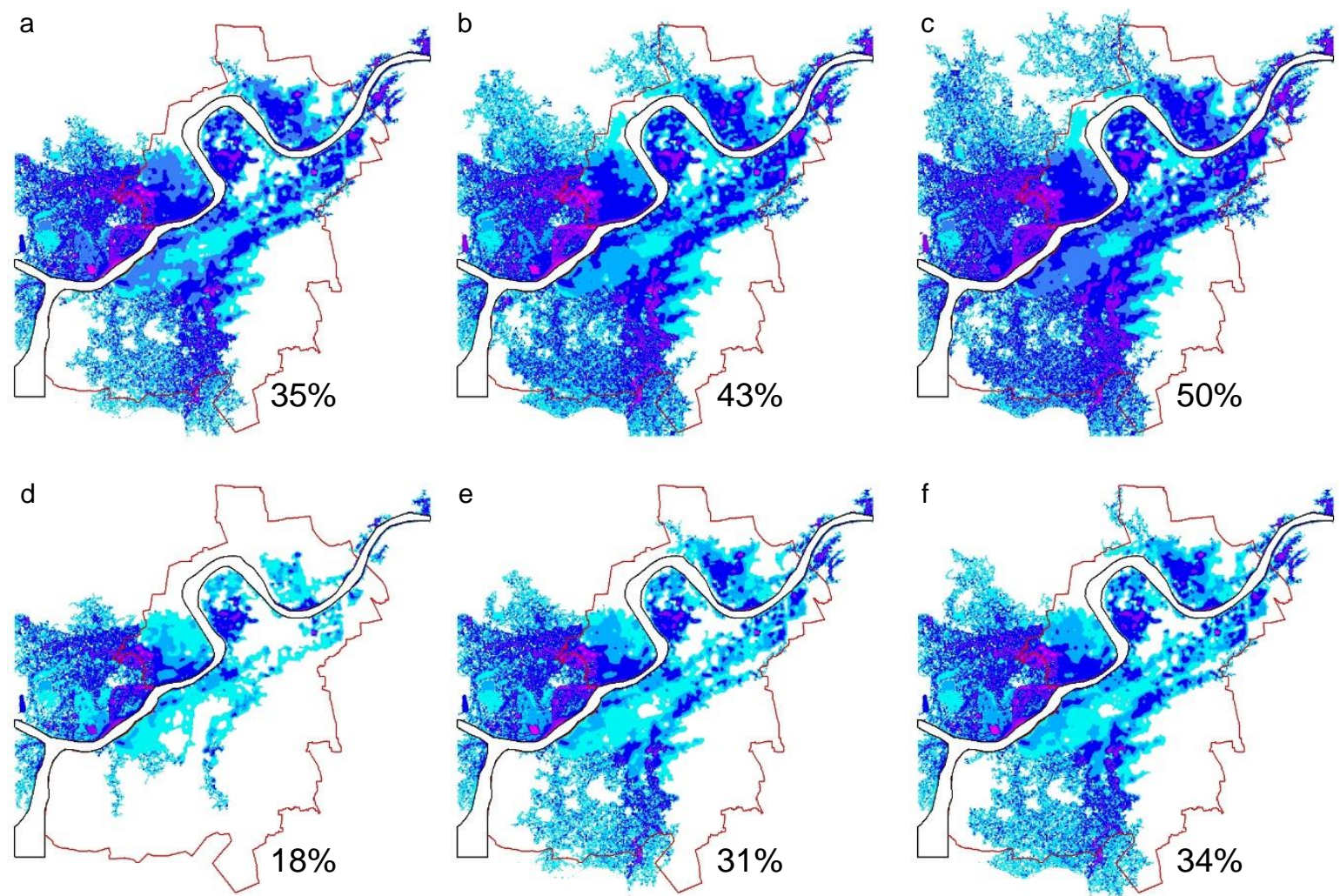

g

$\mathrm{h}$
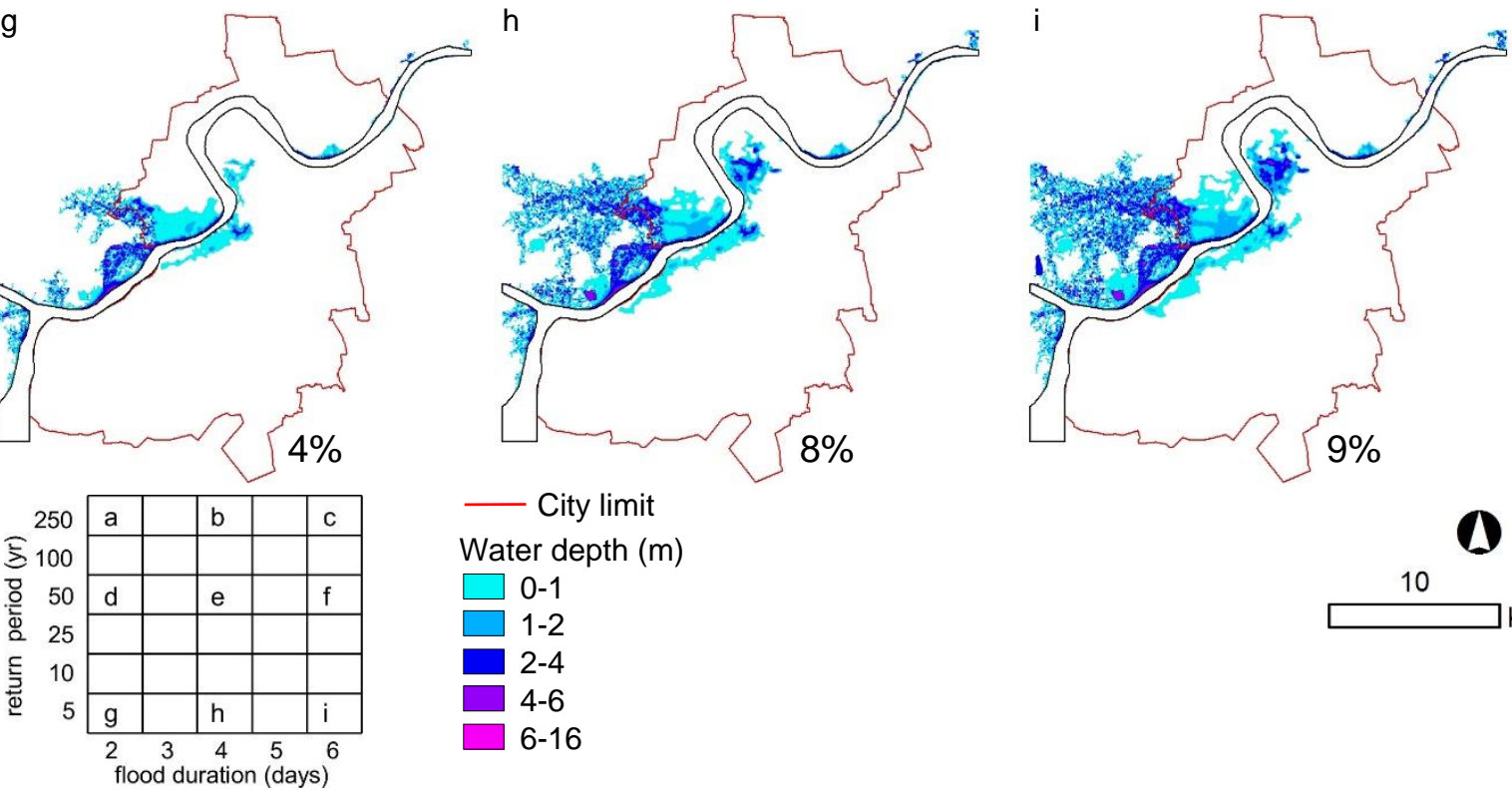

- City limit

Water depth $(\mathrm{m})$

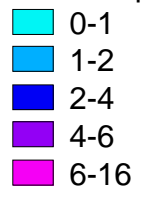

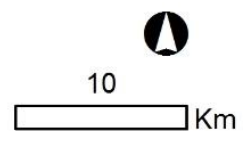

Figure 5: Maximum water depths and spatial extent for Surat floods from dam outflows of different duration and return period (see inset bottom left). Percentage of flood extent indicated. 
Hydrol. Earth Syst. Sci. Discuss., doi:10.5194/hess-2016-544, 2016

Manuscript under review for journal Hydrol. Earth Syst. Sci.

Published: 18 November 2016

(c) Author(s) 2016. CC-BY 3.0 License.
Hydrology and

Earth System

Sciences

Discussions
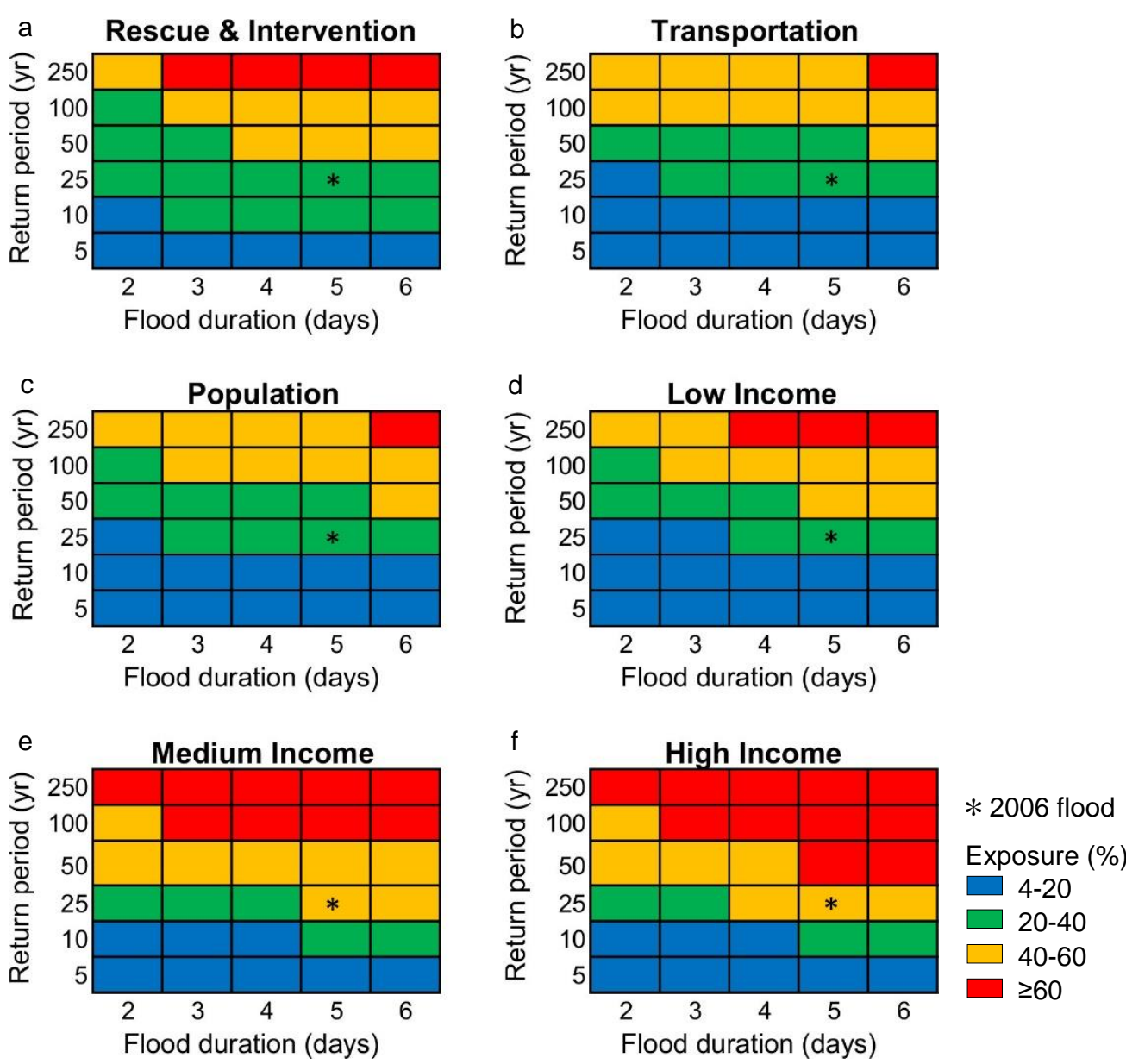

Figure 6: Exposure to very high flood depths $(\geq 0.75 \mathrm{~m}$ ) for (a) rescue $\&$ intervention, (b) transportation, (c) population, (d) low income neighbourhoods, (e) medium income neighbourhoods, and (f) high income neighbourhoods. Asterisk indicates duration and return period of the 2006 flood. 
Hydrol. Earth Syst. Sci. Discuss., doi:10.5194/hess-2016-544, 2016

Manuscript under review for journal Hydrol. Earth Syst. Sci.

Published: 18 November 2016

(c) Author(s) 2016. CC-BY 3.0 License.

\section{Hydrology and Earth System Sciences \\ Discussions}

(c) (i)

Return period (yr)

$\square 5$

$\square$ 5-50

50-250

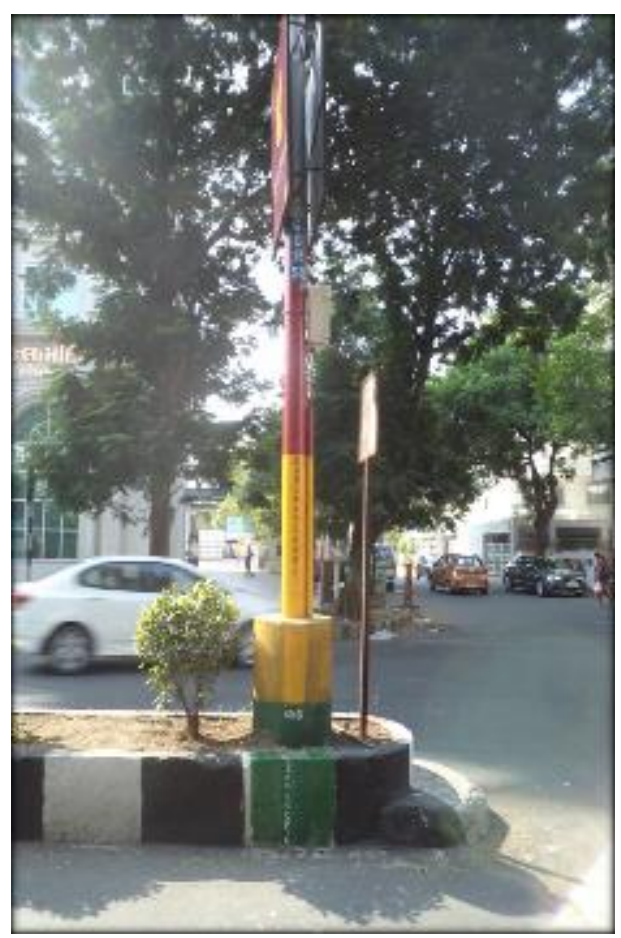

Figure 7: Lamp post in Surat painted with modelled water heights from scenarios with flood duration of three days and indicated return periods. 